\title{
Field research and methodologies for textile industry innovation in the context of European economy
}

\author{
DOI: 10.35530/IT.071.01.1623
}

\section{ABSTRACT - REZUMAT}

Field research and methodologies for textile industry innovation in the context of European economy

This paper presents several aspects concerning the field and desk research based on the methodologies in the context of the European economy. Also, this work presents brief aspects about innovation, fundamental, applied research and needs of training in the textile sector for managers, students, assistant managers and experts from Romania. A survey-based on questionnaires and statistical analysis was performed, in order to achieve the landscape of training needs in the area of the Bucharest region.

Keywords: textile, field research, methodology, economy, innovation

Inovarea în domeniul cercetării şi metodologiilor pentru industria textilă în contextul economiei europene

În această lucrare sunt prezentate câteva aspecte privind domeniul şi instrumentele necesare cercetării pe baza metodologiilor impuse în contextul economiei europene. De asemenea, în cadrul acestei lucrări sunt prezentate pe scurt aspectele privind inovarea, cercetarea fundamentală, aplicativă şi nevoile de pregătire în domeniul textil pentru directori, asistenți manager, studenţi şi experţi din România. Pentru a obţine o viziune de ansamblu asupra nevoilor de cursuri în regiunea Bucureşti a fost realizat un studiu pe baza chestionarelor şi a analizei statistice.

Cuvinte-cheie: textile, domeniul de cercetare, metodologie, economie, inovare

\section{INTRODUCTION}

The innovation represents a new idea, method, device or a change made to an existing product, idea, or field. Many times the term innovation is confused with the invention term that represents a device, technology, or process generated after study and experimental part [1]. Several authors present innovation metaphorically as "creator and destroyer of industries and corporations", describing a model of survival for companies, namely to keep a balance between supporting new and established innovations [2]. Also, innovation is described as a specific tool of entrepreneurs, how they exploit change as an opportunity for a different business or service. Besides, the entrepreneurs should search for the source of innovation, the change, and the opportunities for successful innovation. In this paper, innovation is defined as an "act that endows resources with a new capacity to create wealth. Innovation, indeed, creates a resource useful for something and thus endows it with economic value" [3].

Some researchers presented in antithesis the debut of the innovation product vs. process innovation, and they state that the "product innovation starts high and decreases rapidly and the process innovation increases over time" [4] (figure 1).

The innovation is defined as being "not simply developing new technologies into new products or services, but in many cases finding new models for doing business in the face of change". For example, in 2006, "Threadless, an online T-shirt company founded in 2000 , had profits of $\$ 6$ million on revenues of $\$ 18$ million, from T-shirts that had been designed, marketed, and bought by members of the public". This business model user-centered is considered the most profitable in the clothing retail business [5].

The basic types of research are descriptive, analytical, applied, fundamental, qualitative and quantitative.

In 2011, Kumar, R., claimed that basic research consists "in developing and testing theories and hypothe-

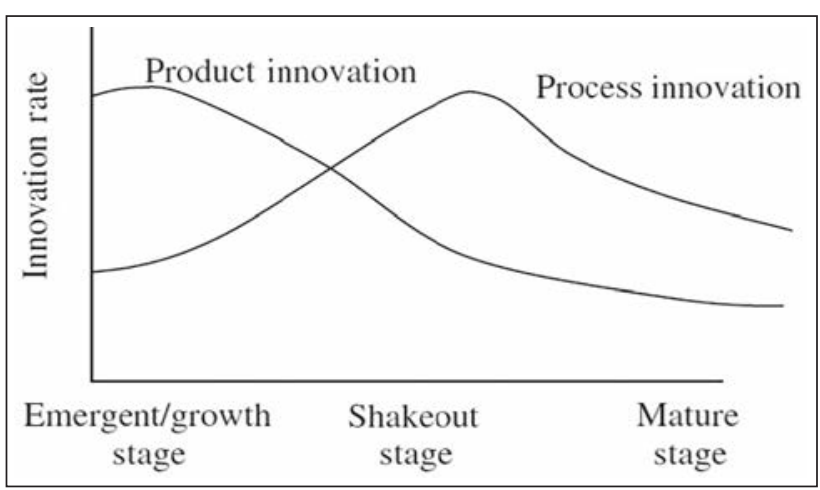

Fig. 1. The relative importance of product as opposed to process innovation throughout the industry life cycle. Source: Adapted from Abernathy and Utterback, 1978 [4] 
ses that are intellectually challenging to the researcher but cloud or not to have a practical application at present or in the future". The hypotheses tested are based on very abstract and specialized concepts. Fundamental research also refers to the development, examination, verification, and refinement of research methods, procedures, techniques and tools for the research methodology [6]. The goal of fundamental research is to develop universal knowledge and to discover statistically significant correlations and effects [7]. The applied research is defined as the method of finding a solution for an immediate problem facing a society or an industrial/business organization [8]. Applied research develops information for clarifying or verifying an immediate social problem. "Fundamental and applied research differ in purposes, context and methods" (table 1). The applied research goal is to understand, to address problems and to discover practically significant effects or correlations [8].

Table 1

DIFFERENT CONTEXTS - FUNDAMENTAL VS. APPLIED RESEARCH

\begin{tabular}{|c|c|}
\hline Fundamental & Applied \\
\hline Academic settings & $\begin{array}{c}\text { Government, foundation, } \\
\text { research institutes, } \\
\text { business/industrial setting }\end{array}$ \\
\hline Self-initiated & Client initiated \\
\hline Funded by grants & Funded by contracts \\
\hline Single researcher & Research team \\
\hline Single discipline & Multidisciplinary \\
\hline Lab or class & Field \\
\hline Flexible & Inflexible \\
\hline Lower cost sensitivity & Higher cost sensitivity \\
\hline Less time pressure & More time pressure \\
\hline
\end{tabular}

\section{BACKGROUND AND CONTEXT ANALYSIS OF RESEARCH \& INNOVATION IN THE TEXTILE AND CLOTHING MANUFACTURING SECTOR IN EUROPE}

The leading producers of textiles and fashion goods in the EU are Italy, Germany, France, Spain, Portugal, UK, Belgium, Poland, Romania, and Austria. They produce clothes, carpets, home textiles, cellulosic fibers and technical textiles used in various sectors [9-10]. In Europe, textile and fashion companies are predominantly SMEs. They directly employ 1.69 million people, $70 \%$ of whom are women. Romania is the $2^{\text {nd }}$ largest employer in textile industry (figure 2).

The statistics regarding the total employment figures for the textile and clothing manufacturing industry in the European Union (EU28) from 2009 to 2018, split the employment by segment (man-made fibers, clothing, and textile). Of the three segments, the clothing manufacturing industry employed the most

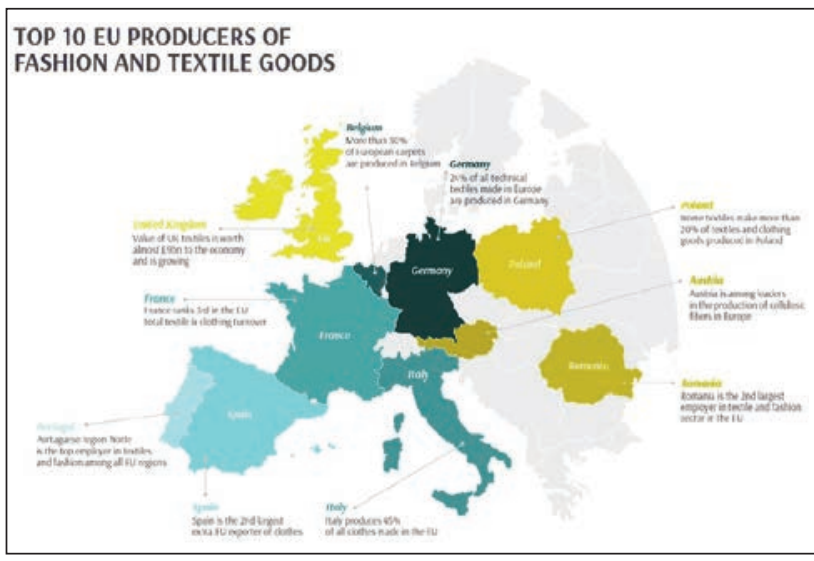

Fig. 2. European producers - top 10 [9]

significant number of people. In 2017, the clothingmanufacturing industry employed around 1.01 million people and in 2018, around 0.987 (figure 3). By analyzing the employment in the textile industry between 2009 and 2018 can be observed a decreasing tendency.

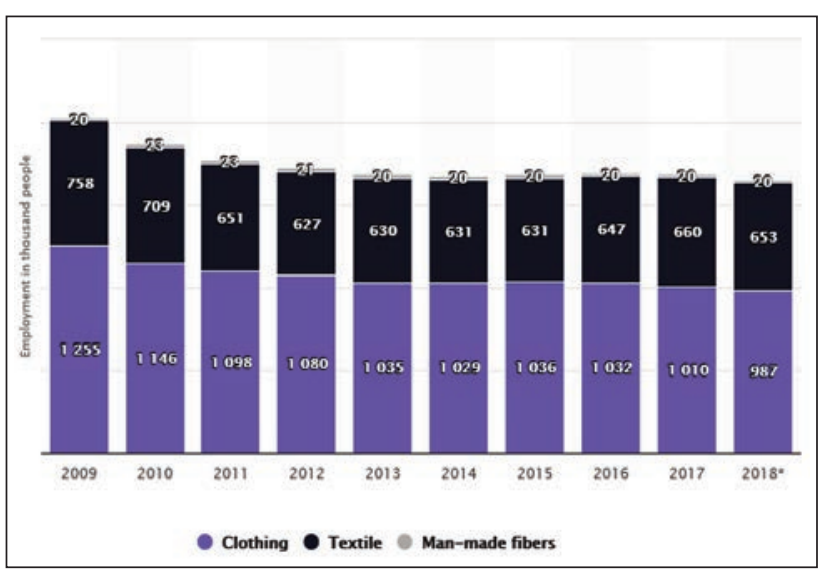

Fig. 3. Total employment in textile and clothing manufacturing industry in Europe 2009-2018 [10]

In figure 4 the statistic presents the main five global import markets for clothing coming from outside the European Union-28, ranked by their value from 2015 to 2018. China ranked as the leading clothing supplier, with imports to the EU valuing at approximately 29.9 billion euros in 2018. Among the various EU countries, the United Kingdom (UK) had the thirdhighest value of clothing imports in 2016, following Germany and France. This aspect is due to the prominence of leading clothing retailers, such as Primark and Next, which have a strong store presence in the country. As of September 2017 there were, for example, 182 Primark stores in the UK. The United Kingdom also has an active export market for clothing, albeit not as strong as its import values, with exports nearly doubling over 16 years, to 8.1 billion U.S. dollars in 2016.

This statistic shows the revenue of the manufacture of other textiles in Romania [12-14] by segment from 2010 to 2015 , with a forecast to 2022. The global view shows that the revenue of the manufacture of 
other textiles in Romania will be approximately 1,113 million U.S. dollars by 2022 (figure 5).

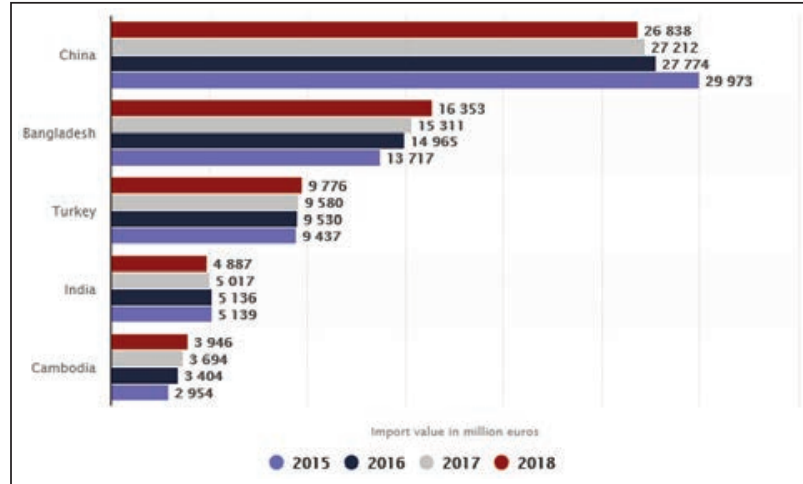

Fig. 4. The main five global import markets for clothing coming from outside the European Union-28, ranked by their value from 2015 to 2018 [11]

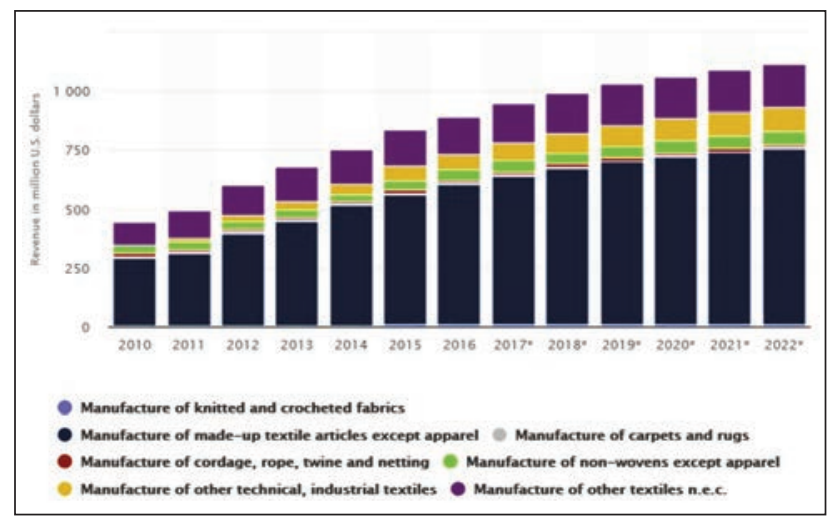

Fig. 5. Revenue of manufacture of other textiles in Romania by segment from 2010 to 2015 , with a forecast to 2022 [12]

\section{FIELD RESEARCH METHODOLOGY FOR BUCHAREST REGION}

Our field research is based on survey questionnaires and was designed according to standard research methodology. The field research was applied to the following two groups of respondents:

- Group 1: Managers and professionals from T\&C industries;



- Group 2: Relevant experts (experts from HEls, VET professionals, intermediary organizations belonging to textiles and clothing sector).

The outputs of field research consist in info about:

- Perceived training needs related to research \&innovation of managers and professionals of textile and clothing manufacturing industries;

- Perceived problems, challenges, new functionalities, gaps and mismatches existing in the sector;

- Inputs from HEI experts, VET professionals, intermediary organizations about the requested needs of the sector in terms of innovation.

Perceived training needs related to research \& innovation

Concerning the question about the staff needs further training related to research and innovation, $86 \%$ of respondents gave a definite answer while a respondent gave a negative answer. Concerning the perceived training needs, in the region Bucharest-Ilfov the answers distributions (figure 6, a) shows that it is a strong need for modern production methods and project management concepts, while for non-technical aspects of advanced manufacturing specific to the T\&C [15-16] sector and traditional textiles and clothing technologies are considerable needs for training. Besides, it is a weak interest in training for functionalization methods and processes for textiles and sustainable value chains specific to T\&C sector. All respondents have selected as considerable aspects such as creativity for the development of textile materials and products, digital skills, market trend analysis and risk management in R\&D (figure 6, b).

Perceived problems, challenges, new functionalities, gaps and mismatches existing in the sector

The perceived problems, challenges, and gaps were analyzed by using answers from experts and managers/professionals of textile industries involved in the survey.

The experts also specify that the companies do not frequently require $R \& D$ services and the request for project research does not come from companies to

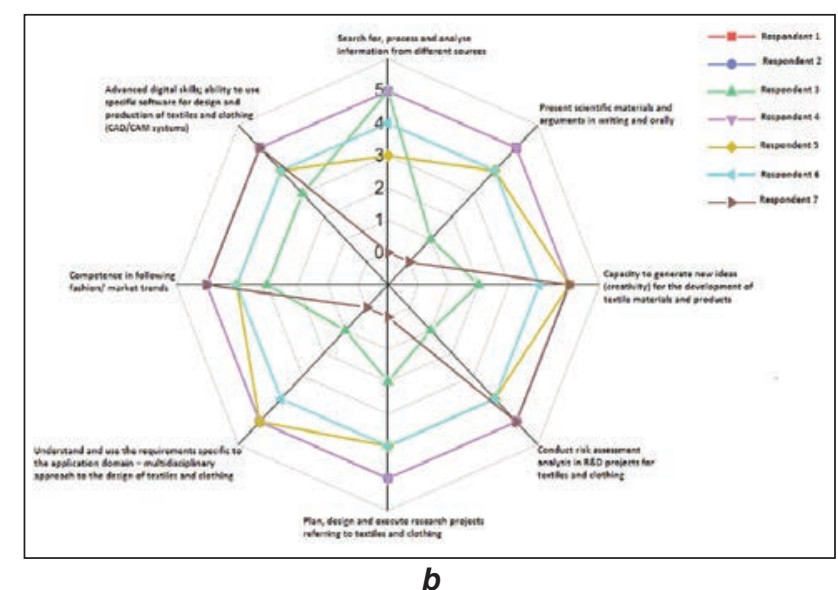

b

Fig. 6. Distribution of the answers about staff needs: $a$ - answers impact for training needs; $b$ - answers impact for skills and competencies needs 


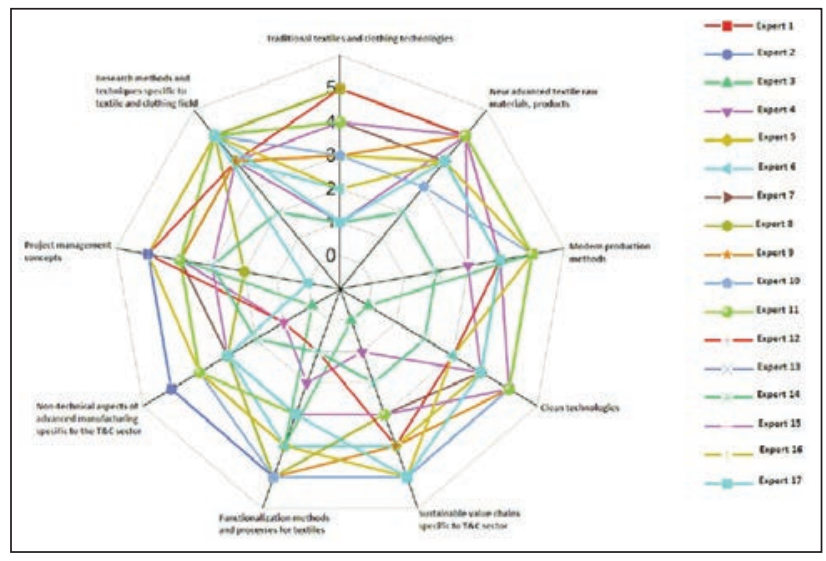

a

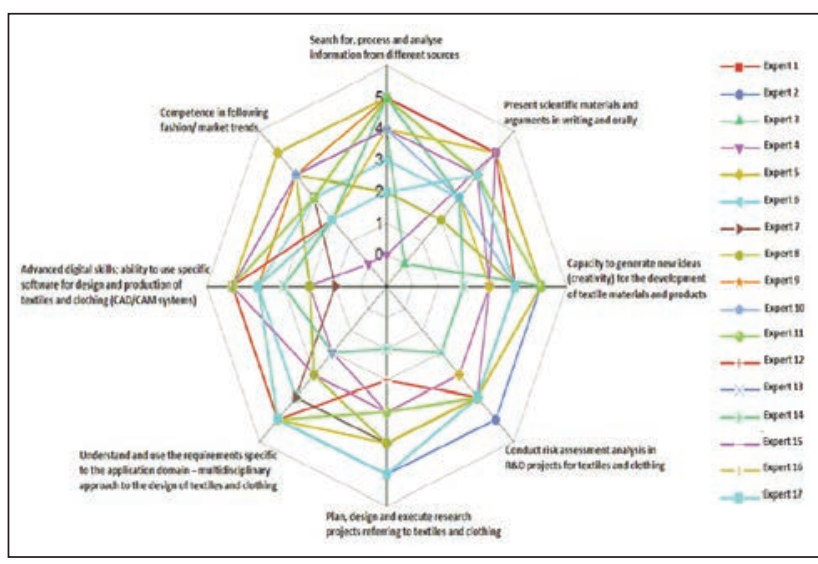

b

Fig. 7. Distribution of the answers concerning training needs, skills, and competencies: $a$ - answers for training needs from experts; $b$ - answers for skills and competencies need from experts

institutes/universities because the companies are not very interested in research and innovation. Moreover, the researchers propose the research themes to companies. Also, experts claim that companies have insufficient experience in R\&D.

Concerning the main problems/challenges about research and innovation in the T\&C sector, $94 \%$ of experts consider that the main problems are the insufficient funds and the difficulties in accessing the fund for research and innovation, while $82 \%$ of experts consider as the primary problem lack of personnel specialized in R\&D activities. Regarding the technology required for developing innovative products, about $76 \%$ of experts consider this aspect a real problem because new technologies are costly.

In the context of insufficiently applied research projects, $76 \%$ of experts consider that the main gaps consist in different visions regarding the research and innovation, while $70 \%$ of experts consider that the institutes or universities and companies have different research agendas and the companies do not trust concerning universities or institutes. Additional gaps observed by experts are:

- Lack of professionalism of the new T\&C industries after 1995;

- The cultural and creative industries that emerged after 2005, are not recognized by the universities and the proper research.

Concerning the main problems, $86 \%$ of managers consider that the funds are insufficient and the access is difficult, while $57 \%$ consider that the absence of three key factors, such as technology, specialized personnel in R\&D and the market for innovative products, represents a problem. Besides, $43 \%$ of managers consider that the problem consists of lack of IPR knowledge.

Regarding the main gaps about research and innovation, $71 \%$ of the managers consider that central gap consists in the fact that HEls/research institutes and companies have different research agendas, while $57 \%$ consider that companies perceive research and innovation differently and $43 \%$ of the managers consider that are insufficient research projects.
Inputs from HEI experts, VET professionals, intermediary organizations about the requested needs of the sector in terms of innovation

By analyzing the mean values for the scores provided by experts for training needs (figure 7), it should be noted that the experts consider that the essential training programs are related to research methods and techniques specific to textile and clothing field, new advanced textile raw materials and products and modern production methods. With a score below four, the experts appreciate that clean technologies and project management are essential.

By analyzing the mean values for the scores provided by experts for skills and competencies needs (figure $7, a$ and $b$ ), it is evident that the experts consider as relevant competencies the capacity to analyze and understand the information, creativity, digital skills, and risk analysis. Regarding the innovation in the T\&C sector, 14 experts consider that innovation in the T\&C sector should refer to both technological and non-technological innovation.

In addition, we received from experts supplementary suggestions concerning:

\section{- Training needs:}

The first suggestion was to learn how to elaborate validation method accredited by RENAR.

The second suggestion was to introduce new courses about textile ecology and circular economy based on textile recycling.

The third suggestion was to introduce basic concepts about human-centered production, social design, industrial design and T\&C Business.

\section{- Skills and competencies:}

The suggestion is to develop or improve skills such as the ability to analyze, synthesize contradictory information and visionary thinking.

\section{CONCLUSIONS}

In conclusion, the experts have indicated certain aspects of improvement, such as:

- The selected training needs should be the starting point for adaptation or creating new courses. 
- The results of this survey must be addressed to the companies, research institutes, universities, and all policymakers.

Also, some experts consider that should be more issues addressed by deliverable, such as:

- The distribution of age groups in research;

- The percentage of public funding about private financing;

- The need to work in a research team with members having a high level of scientific expertise.

This study is useful for educational institutions (universities, institutes of technology, academies), enterprises (suppliers, R\&D centres, innovation lab, pools), public bodies (chambers of commerce, local governments, professional associations) and users (students, manufacturing companies, creative companies, teachers, researchers, designers, project managers) at European, national and regional levels.

\section{ACKNOWLEDGMENTS}

The research presented in this paper was prepared in the INCDTP. Funds support this work are from Erasmus+ Strategic Partnership for Higher Education, TEXSTRA Project, Contract 2017-1-RO01-KA203-037289, funded by European Commission.

This project has been funded with support from the European Commission. This publication [communication] reflects the views only of the author, and the Commission cannot be held responsible for any use which may be made of the information contained therein.

\section{Co-funded by the Erasmus+ Programme of the European Union}

\section{REFERENCES}

[1] Innovation definition, [online] Available at: https://www.merriam-webster.com/dictionary/innovation [Accessed 6 May 2018]

[2] Utterback, J., Mastering the dynamics of innovation: how companies can seize opportunities in the face of technological change, University of Illinois at Urbana-Champaign's Academy for Entrepreneurial Leadership Historical Research Reference in Entrepreneurship, 1994

[3] Drucker, P.F., Noel, J.L., Innovation and Entrepreneurship: practices and principles, 1986

[4] Shane, S., The handbook of technology and innovation management, ed. John Wiley \& Sons, 2008

[5] Afuah, A., Strategic innovation: new game strategies for competitive advantage, Routledge, 2009

[6] Kumar, R., Research Methodology, Sage, Malaysia, 2011

[7] Hedrick, T.E., Bickman, L., Rog, D.J., Applied research design: A practical guide, 1993

[8] Kothari, C.R., Research methodology: Methods and techniques, New Age International, 2004

[9] Annual report EU textile \& fashion industry: Facts and Figures, 2016

[10] Total employment in textile and clothing manufacturing industry in Europe, [online] Available at: https://www.statista.com/statistics [Accessed 20 May 2019]

[11] The main five global import markets for clothing coming from outside the European Union-28, ranked by their value from 2015 to 2018, [online] Available at: https://www.statista.com/statistics [Accessed 14 May 2019]

[12] Revenue of manufacture of other textiles in Romania by segment from 2010 to 2015, with a forecast to 2022, [online] Available at: https://www.statista.com/statistics [Accessed 14 May 2018]

[13] Florescu, M.S., Ivanov, F., Globalization as a factor of influence on the R\&D activity and the case of the textile industry in Romania, In: Industria Textila, 2016, 67, 5, 345-350

[14] Tudor, L., Change in Textile and Clothing Industry, In: Industria Textila, 2018, 69, 1, 37-43, http://doi.org/ 10.35530/IT.069.01.1449

[15] Rădulescu, I.R., Almeida, L., Vannucci, R., Blaga, M., Dufkova, P., Stjepanovič, Z., Texmatrix - The knowledge matrix for innovation applied to textile enterprises, In: Industria Textila, 2019, 70, 2, 197-202, http://doi.org/ 10.35530/IT.070.02.1648

[16] Radulescu, I.R., Stjepanovic, Z., Dufkova, P., Almeida, L., Blaga, M., E-learning in advanced textiles, In: Industria Textila, 2017, 68, 3, 226-231, http://doi.org/10.35530/IT.068.03.1342

\section{Authors:}

\section{RALUCA MARIA AILENI, LAURA CHIRIAC, LILIOARA SURDU, RAZVAN ION RADULESCU}

National Research \& Development Institute for Textiles and Leather, Lucretiu Patrascanu no.16, 030508, Bucharest, Romania

Corresponding author:

RALUCA MARIA AILENI

e-mail: raluca.aileni@incdtp.ro 